\title{
Courtyard as Passive Design Solution for School Buildings in Hot Area
}

\author{
Muna Salameh", and Hanan Taleb ${ }^{3}$ \\ ${ }^{1}$ Ajman University \\ UAE \\ 2014139085@student.buid.ac.ae \\ ${ }^{2}$ Architecture and Sustainable Built Environment, British University in Dubai \\ UAE \\ ${ }^{3}$ Sustainable Design of Built Environment, British University in Dubai \\ $\mathrm{UAE}$ \\ hanan.taleb@buid.ac.ae
}

\begin{abstract}
Sustainability in architecture must produce buildings that give satisfaction for people with less energy consumption and less environmental problems. The sustainable design in architecture adopts passive design strategies like courtyards that produce buildings which use the wind for cooling and the sun for lighting and heating. The courtyard was a climate responsive design in the past, that provided people with easy direct solutions for their problems with the climate, and it was able to satisfy their social needs. In this study there will be an investigating for the effect of closed courtyard with different proportions on school building in UAE, to test the capability of the closed courtyard in improving the thermal performance of the school building consequently minimize the energy consumption. The study adopted a school building as a case study because courtyards are used mostly in houses while it can be beneficial for public buildings like schools. Courtyard can provide the school with private outdoor space, and can improve the thermal and ventilation properties of the school building thus minimize the energy consumption. Moreover the courtyard can provide the school with safe inner playground and learning scientific atmosphere for the students. The study will adopt a qualitative methodology which depends on descriptive and comparative analysis for the case study after the computer simulation with the Integral Environmental Solutions software (IES). After investigating the case study with different courtyard proportions and with the aid of the computer simulation, there was energy savings for the building because of the presence of the closed courtyard but with different values related to the proportions of the courtyard. The final result indicated that the courtyard effects the amount of the sun exposure, solar gain consequently the cooling sensible plant of the building, moreover the courtyard design and proportions have a direct effect on the ventilation beside the thermal performance of the interior spaces. However the courtyard should be in proportions that suits the height and the function of the building.
\end{abstract}

Keywords: Sustainability, Passive design strategies, Courtyard, Energy efficiency, School building, UAE

\section{Introduction}

Architecture is an important component to create sustainable environment with less energy consumption [1]. The traditional concepts for design become the core of the vernacular and sustainable architecture, most of these concepts known as passive design strategies [2]. These strategies are integrated in the buildings design to improve the indoor thermal circumstances with less energy consumption [3]. Rajapaksha, Nagai and Okumiya highlighted the courtyard as important component among the passive design solutions in the humid warm areas [4]. The courtyard as a traditional strategy [5] can be integrated in the contemporary architecture in all the types of the buildings but with suitable ratios to make it more effective in improving the thermal conditions.

\section{Literature Review}

\subsection{Courtyard shapes and types}

Courtyard can be formed in square, rectangular or circular outline. Reynolds (2002) indicated that most of the courtyards in the past were designed as square or rectangular shape [6]. In the meantime Edwards et al. (2006) stated that 
circular courtyards can be seen in the vernacular architecture of the traditional samba village [7]. Hyde (2000) listed the common three design types of courtyards which are closed, semi closed and semi opened courtyard [8], as shown in Figure 1. The closed courtyard is common in deep plans as it provides high level of privacy, lighting and good ventilation. On the other hand the semi closed courtyard is usually created between buildings and assumed to be a semi private zone that has shaded area. Finally the semi opened courtyard provides the smallest amount of privacy but at the same time it provides direct access, ventilation and vision for the building.

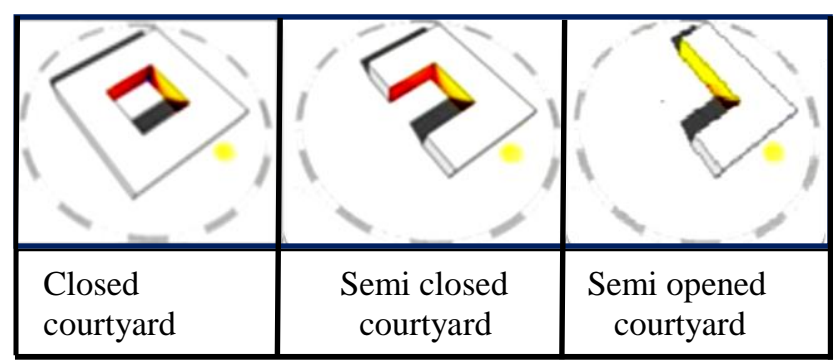

Fig. 1: Courtyards types [8].

\subsection{Courtyard ratios and thermal behavioral}

The courtyard can improve the thermal conditions of the buildings in hot areas [9],[10]. Koch-Nielsen (2013) confirmed that the thermal characteristics for the courtyard and for the surrounding spaces are mainly determined by the courtyard proportions [11]. He added that the best recommended proportions are related to the height of the building, if the height of the courtyard is X it is better to have width that ranges from X to 3X. Manioglu and Oral (2015) stated that the courtyard proportions (width to length) effect its thermal performance [12]. Soflaei, Shokouhian and Mofidi (2016) and Almhafdy et al. (2015) concluded that the thermal behavior of the courtyard is defined by its dimensions and proportions in hot areas [13],[14]. They added that the proportions of the courtyard have a significant effect on the building solar gain and cooling loads.

\subsection{Courtyard in schools}

Most of the studies related to courtyards were about the courtyards effects on buildings in general. Limited number of studies discussed the school courtyard and they were focusing on the ventilation, courtyard landscape role, adjusting the noise,...etc. [15],[16],[17],[18]. There was a gap in the literature related to the thermal effects of courtyards combined with the school buildings, as this was seldom discussed in the previous researches. Courtyards were mainly related to houses as passive design solution to improve the thermal behavior and the ventilation of the houses and buildings in general. This study will inspect facts related to the courtyards as passive design solution for school buildings in hot and arid climates.

\section{Methodology}

The research will adopt a qualitative methodology which depends on comparative analysis for a case study after computer simulation; the case study will be a school building in Sharjah.

Computer simulation: Virtual Environment software (IES) will be used for the simulation of the case study to investigate the environmental performance of the closed courtyard in a school building. Crawle et al. (2008) declared the accuracy and the rationality of the IES software in simulating the environmental performance of the buildings [19].

\subsection{Case study}

The case study is Al Murooj English school which is located in Sharjah in UAE as shown in Figure 2. The dry desert climate is dominant in all UAE emirates including Sharjah [20]. Refer to Figure 3 and 4 for the average temperature and the dry and wet bulb temperature in Sharjah-UAE. 


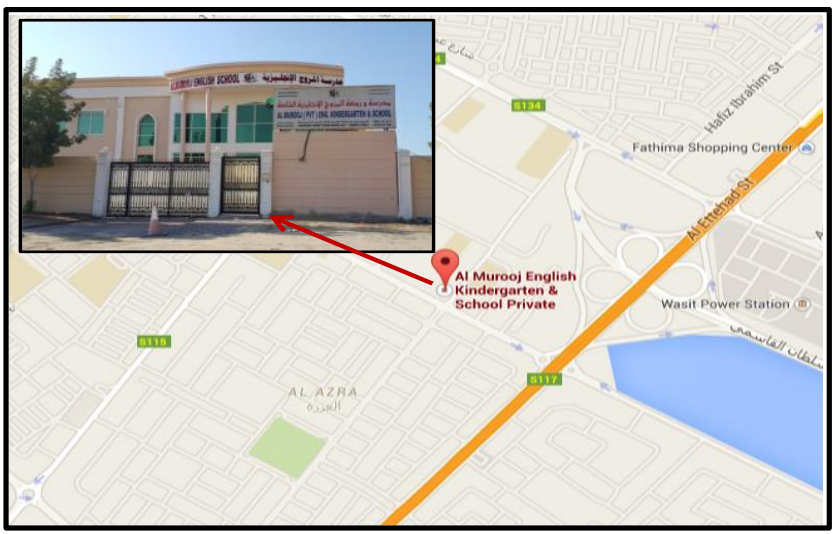

Fig. 2: The case study (Al Murooj English school) location in Sharjah-UAE [21].

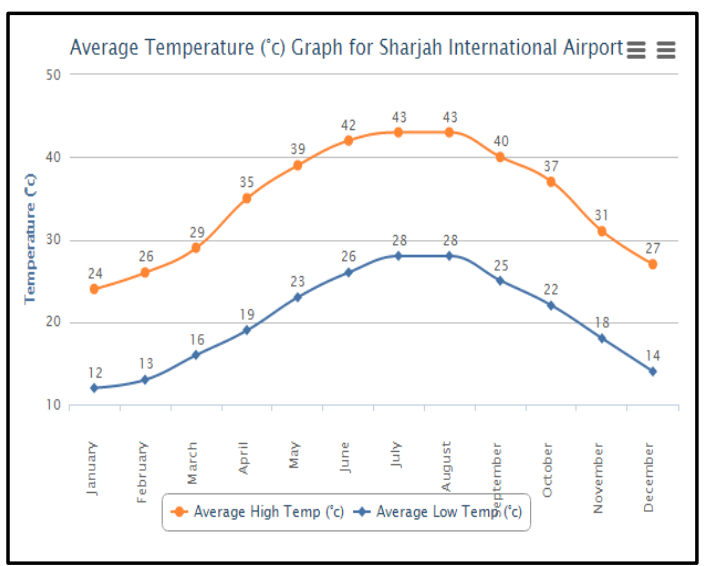

Fig. 3: Average temperature in Sharjah-UAE (IES).

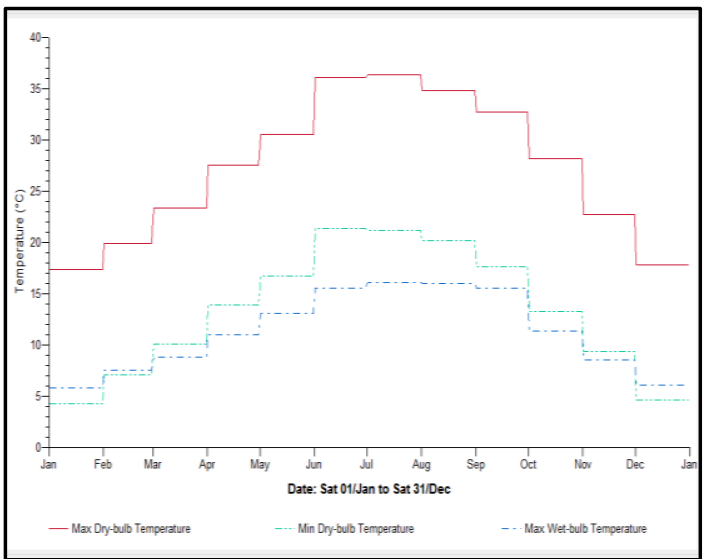

Fig. 4: Dry and wet bulb temperature in Sharjah-UAE (IES). 


\section{The study analysis scope}

In the study there will be an investigation of the thermal performance and ventilation of the original school building with semi opened courtyard (the case study) compared with two proposed cases of the school building with closed courtyards in two different proportions. The closed courtyards were designed according to the suggestions of KochNielsen (2013) as he stated that the size and the height of the courtyard affect strongly the thermal properties of the courtyard and the surrounding spaces. Koch declared that if the height of the courtyard walls is X then the best width for the courtyard is ranging from $\mathrm{X}$ to $3 \mathrm{X}$ [11], as shown in Figure 5. The study will adopt two cases (proportions) for the courtyard which are $2 \mathrm{X}$ and $3 \mathrm{X}$, and the proportion of $1 \mathrm{X}$ will be ignored as it is not suitable for public building because it produces small courtyard that suits more the houses. The investigation will be on three cases as explained in Table 1 to find the optimum proportion for the courtyard in the school building of the case study, toward providing the school with the best thermal performance and ventilation for future expansion. The energy simulation will be for a test room that exists in the first floor and overlooking the courtyard, and it exists in the three cases of the school, the test room is a classroom that occupied by 20 students and has area around $42 \mathrm{~m}^{2}$. The test room assumed to be occupied from 8 morning till 6 afternoon every day. The cooling set point is $20^{\circ} \mathrm{C}$. People and fluorescent lighting were added to the internal heat gain of the test room. Electricity is used for cooling.

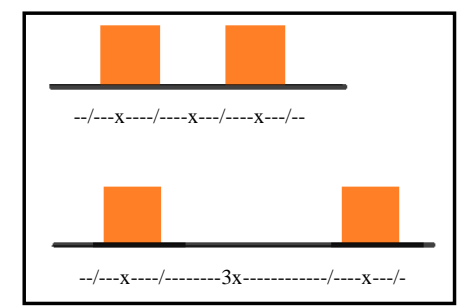

Fig. 5: The courtyard best proportions according to Koch-Nielsen studies [11].

Table 1: The three simulation cases of the study.

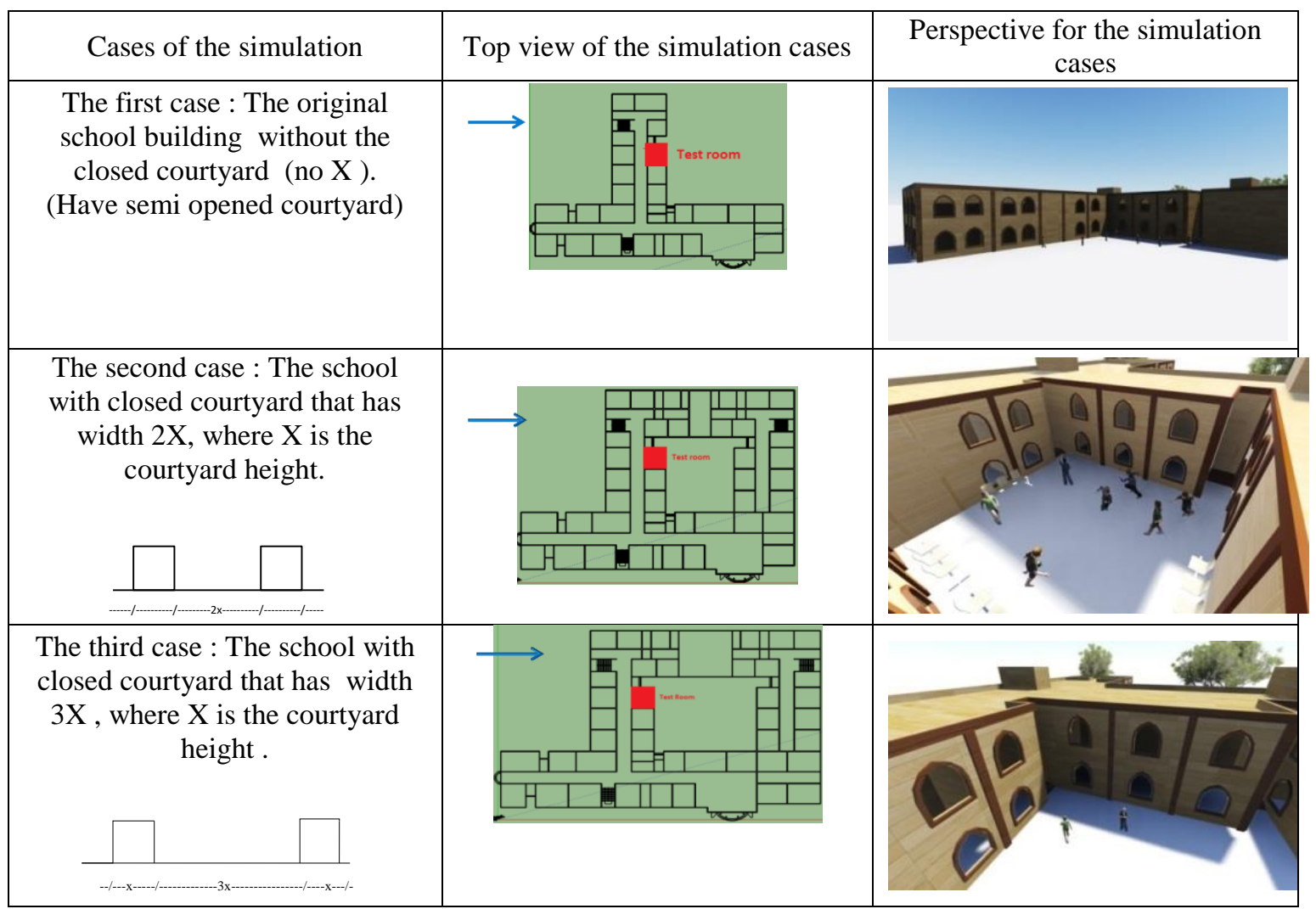


The building materials which are adopted for the simulation are the basic materials that were used in the original school building (for roofs, floors, walls and glazing) which was constructed on 1995, because the study focuses on the effect of the courtyard on the building .Refer to Table 2 for the materials that were used in the school-case study. The materials were defined as standard materials in Dubai regulations for buildings before the year 2002 [22].

Table 2: Building materials of the school that were used in the IES simulation [22].

\begin{tabular}{|l|l|l|}
\hline Building component & Material type & $\mathrm{UV}\left(\mathrm{Wm}^{2} / \mathrm{K}\right)$ \\
\hline Walls & Brick Wall With 4 In. Concrete Block & 1.8709 \\
\hline Glazing & Small Single-Glazed Windows & 5.2298 \\
\hline Roof & 6 In. Heavy Weight Concrete With 2 In. Insulation & 0.6819 \\
\hline Floor/Internal ceiling & 4 In. Light Weight Concrete Deck With False Ceiling & 1.0411 \\
\hline
\end{tabular}

\section{Results and Discussions}

The three cases of the school building which are: original school building without closed courtyard (no X), 2X courtyard school and $3 \mathrm{X}$ courtyard school were simulated in the IES software, the simulation was for the test room in the three cases to investigate the thermal performance and the ventilation.The thermal performance investigation includes sun exposure, cooling plant sensible load, solar gain and the air temperature in the test room. The ventilation investigation includes velocity and local mean age of air surface and $\mathrm{CO} 2$ concentration in the test room.

\subsection{Thermal analysis}

\subsubsection{Sun exposure on the test room}

The sun exposure on the test room was different in the three cases of the school building as shown in Table 3 . The results of the sun exposure were according to the sun path around the school, so most of it was on the north exterior wall of the test room. It was clear that the least hours of sun exposure for the test room was in the case of the $2 \mathrm{X}$ courtyard school, and the highest sun exposure was in the case of no X courtyard school. As a result the north wall of the test room will be less heated in the case of $2 \mathrm{X}$ courtyard, consequently it will make the inner space of the test room cooler than the other two cases and it will need less energy for cooling.

Table 3: Sun exposures on the north wall of the test room (IES 2014).

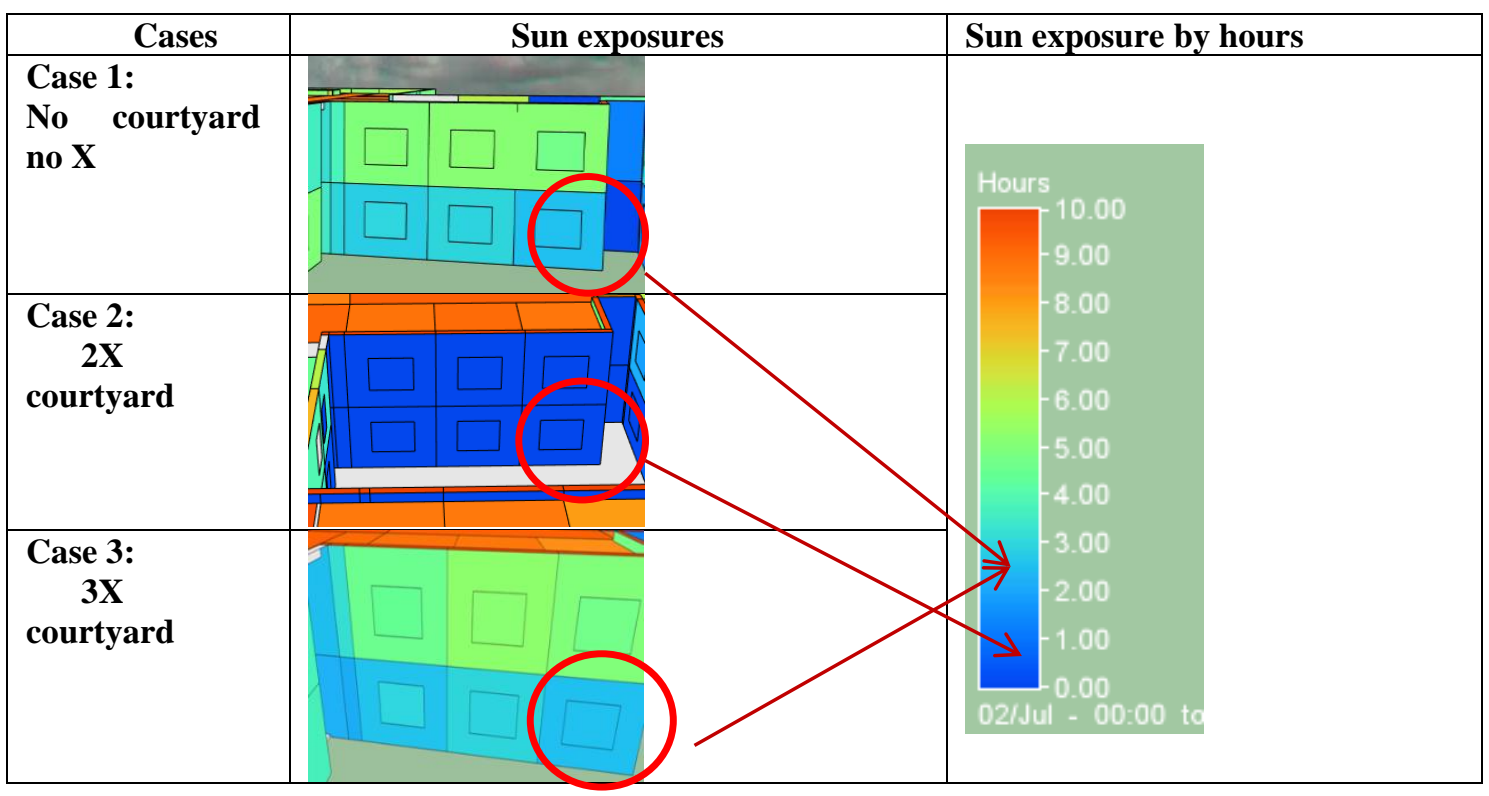




\subsubsection{Cooling plant sensible load}

The cooling plant sensible load indicates the energy consumed for cooling the test room in the three cases of the school building as shown in Table 4. According to Figure 6 it was clear that the least Cooling plant sensible load (KWh) for the test room was in the case of the $2 \mathrm{X}$ courtyard school, as it is $3 \%$ less in Cooling plant sensible load than no $\mathrm{X}$ courtyard school and $2 \%$ less than $3 \mathrm{X}$ courtyard school. Therefore the best case is $2 \mathrm{X}$ courtyard school as it saves more energy for cooling.

Table 4: Cooling plant sensible load (KWh).

\begin{tabular}{|l|l|}
\hline $\begin{array}{l}\text { Simulation cases of the } \\
\text { school }\end{array}$ & $\begin{array}{l}\text { Cooling plant sensible } \\
\text { load (KWh) }\end{array}$ \\
\hline No Courtyard & 15.0862 \\
\hline 2X Courtyard & 14.6325 \\
\hline 3X Courtyard & 14.9335 \\
\hline
\end{tabular}

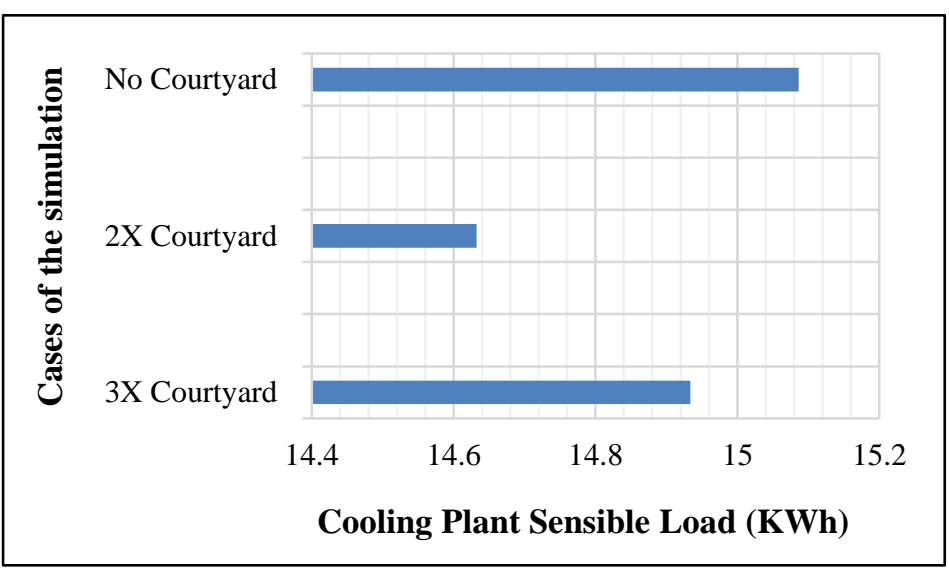

Fig. 6: Graph shows the difference in cooling plant sensible load for the three cases of the school.

\subsubsection{Solar gain for the test room}

The solar gain includes the solar radiation that penetrates the interior spaces. Table 5 shows the solar gain for the test room in the three cases of the school building. After comparing the amount of the solar gain in the three cases as in Figure 7 it was clear that the least solar gain (KWh) for the test room was in the case of the 2X courtyard, as it was $25 \%$ less than no courtyard school and $18 \%$ less than $3 \mathrm{X}$ courtyard school, this result can be explained because the $2 \mathrm{X}$ courtyard school has more shaded areas than the other two cases according to its proportions, and that means less energy will be used for cooling the interior space for the test room specially in the hot months.

Table 5: Solar gain (KWh) in the test room.

\begin{tabular}{|l|l|}
\hline Simulation cases of the school & Solar gain $(\mathrm{KWh})$ \\
\hline 3X courtyard & 1.0938 \\
\hline 2X Courtyard & 0.9629 \\
\hline No Courtyard & 1.1633 \\
\hline
\end{tabular}




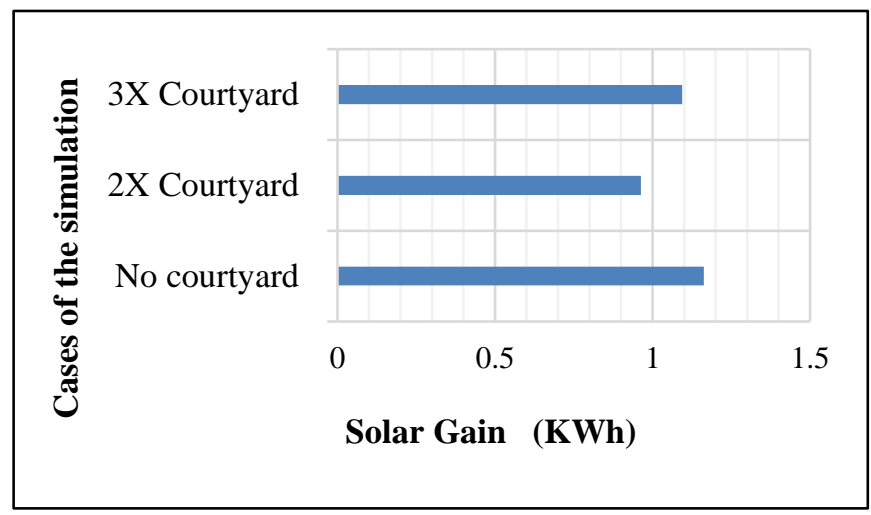

Fig. 7: Solar gain (KWh) in the test room.

\subsubsection{Air temperature in the test room}

It was clear from the simulation that the least air temperature in the test room was in the case of the $2 \mathrm{X}$ courtyard school with mean around $24{ }^{\circ} \mathrm{C}$ as shown in Table 6 , and with significant difference from the school without courtyard and the one with $3 \mathrm{X}$ courtyard as shown in Figure 8. The test room in $2 \mathrm{X}$ Courtyard school is around $23 \%$ less in air temperature than no X courtyard school, and $19 \%$ less in temperature than $3 \mathrm{X}$ courtyard school. The difference in the temperature in the three cases can be explained because the $2 \mathrm{X}$ courtyard school was less in solar gain and solar exposure as was explained before. Therefore the least energy needed for cooling the test room is in the case of $2 \mathrm{X}$ courtyard school.

Table 6: Air temperature in the test room.

\begin{tabular}{|c|c|c|c|c|c|}
\hline \multirow{2}{*}{$\begin{array}{l}\text { Simulation } \\
\text { cases of the } \\
\text { school }\end{array}$} & \multicolumn{2}{|c|}{ Minimum temperature/ test room } & \multicolumn{2}{|c|}{ Maximum temperature /test room } & \multirow[b]{2}{*}{ Mean } \\
\hline & The value ${ }^{\circ} \mathrm{C}$ & The date & The value ${ }^{\circ} \mathrm{C}$ & The time & \\
\hline 3X Courtyard & 17.44 & $27 /$ Jan & 41.56 & 06/Aug & 30.03 \\
\hline 2X Courtyard & 17.43 & 29/Jan & 36.10 & 06/Aug & 24.21 \\
\hline No Courtyard & 18.34 & $27 /$ Jan & 43.73 & 06/Aug & 31.67 \\
\hline
\end{tabular}

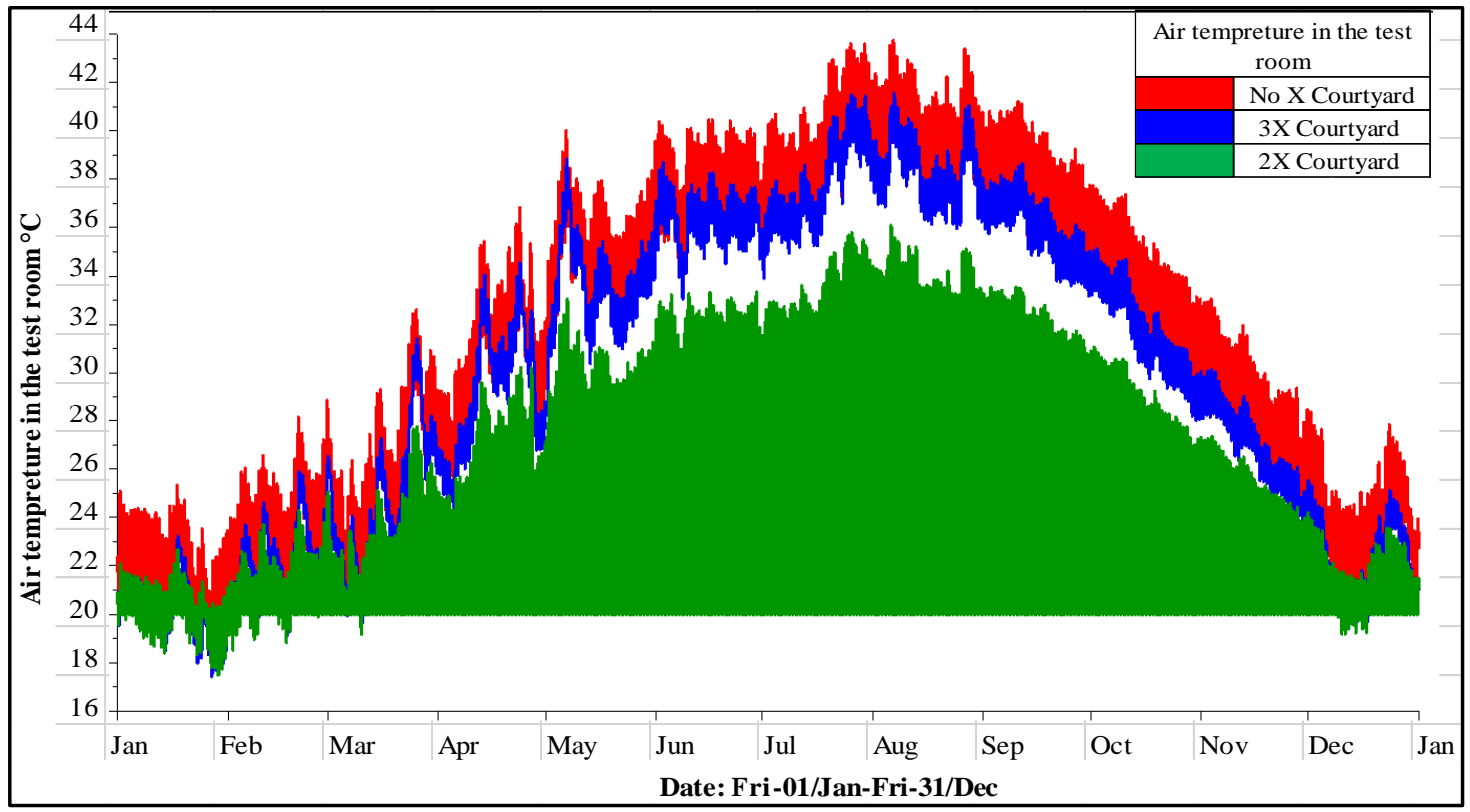

Fig. 8: Air temperature in the test room. 


\subsection{Microflo CFD}

The Computational Fluid Dynamics (CFD) in the IES software was used to check the velocity of the air inside the test room in the three cases of the school based on natural ventilation. The microflo CFD was calculated on the 27th of April at 7:30 at the macro flow external vent in the IES. The microflo CFD analysis were used to investigate the effect of the closed courtyard on the air velocity, local mean age and $\mathrm{CO} 2$ Concentration thus the ventilation in the test room.

\subsubsection{Velocity and local mean age of air surface}

The velocity of the air inside the test room is related to the local mean age of air surface inside it, as when the air velocity is high the age of the air surface inside the test room is short and the air renewed more quickly. In Table 7 it is clear that the higher air velocity in the test room was in the case of $2 \mathrm{X}$ courtyard school, with maximum reading around $0.94 \mathrm{~m} / \mathrm{s}$. Consequently the least age for the local air surface was in the test room in the case of $2 \mathrm{X}$ courtyard school as it ranges from $0.749-7.498 \mathrm{~min}$, and that can be explained in relation to the high velocity of air surface in it as mentioned before. Therefore the fast air movement increases the rate of evaporative heat loss inside the test room and that leads to lower temperature and less energy consumption for cooling. Furthermore the ventilation in the test room in the $2 \mathrm{X}$ courtyard school is the best as the movement of air is faster than the other two cases.

Table 7: Velocity and local mean age of air surface inside the test room.

\begin{tabular}{|c|c|c|c|c|}
\hline $\begin{array}{c}\text { Cases of } \\
\text { the } \\
\text { simulation }\end{array}$ & Velocity & of the air in the test room $\mathrm{m} / \mathrm{s}$ & Local mean & age of the air surface \\
\hline Case 1: & $\mathrm{m} / \mathrm{s}$ & & Min & \\
\hline No closed & 0.55 & & \begin{tabular}{|l|}
12.115 \\
\end{tabular} & \\
\hline courtyard & 0.49 & & 11.01 & \\
\hline school & 0.44 & & 9.912 & \\
\hline & 0.38 & & 8.811 & \\
\hline No $X$ & 0.33 & & 7.709 & \\
\hline & 0.27 & & 6.608 & \\
\hline & 0.22 & & 4.405 & \\
\hline & 0.17 & & 3.304 & \\
\hline & 0.11 & & 2.202 & \\
\hline & 0.06 & & 1.101 & \\
\hline & 0.00 & & 0.000 & \\
\hline & Velocity & & LMA & \\
\hline Case 2: & $\mathrm{m} / \mathrm{s}$ & & $\min$ & \\
\hline & 0.94 & & 7.498 & \\
\hline courtyard & 0.88 & & 6.749 & \\
\hline school & 0.78 & & 5.999 & \\
\hline & 0.66 & & 5.249 & \\
\hline & 0.57 & & 4.499 & \\
\hline & 0.45 & & 3.749 & \\
\hline & 0.38 & & 2.999 & \\
\hline & 0.29 & & 2.249 & \\
\hline & 0.19 & & 1.499 & \\
\hline & 0.09 & & 0.749 & \\
\hline & 0.00 & & 0.000 & \\
\hline & Velocity & & LMA & \\
\hline Case 3: & $\mathrm{m} / \mathrm{s}$ & & $\min$ & \\
\hline $3 \mathrm{X}$ & 0.89 & & 7.682 & \\
\hline courtyard & 0.80 & & 6.914 & \\
\hline school & 0.71 & & 6.145 & \\
\hline & 0.62 & & 5.377 & \\
\hline & 0.53 & & 4.609 & \\
\hline & 0.44 & & 3.841 & \\
\hline & 0.36 & & 3.072 & \\
\hline & 0.27 & & 2.304 & \\
\hline & 0.18 & & 1.536 & \\
\hline & 0.09 & & 0.768 & \\
\hline & 0.00 & & 0.000 & \\
\hline & Velocity & & LMA & \\
\hline
\end{tabular}




\subsubsection{CO2 concentration}

After investigating the $\mathrm{CO} 2$ levels in the test room, it was clear from the simulation that the least $\mathrm{CO} 2$ Concentration (ppm) in the test room was in the case of the $2 \mathrm{X}$ courtyard school with amount around $448 \mathrm{ppm}$ as shown in Table 8 . This amount assumed to be in the suitable range, referring to what was mentioned in the health state report that the CO2 concentration in the inner rooms should range from several hundreds to one thousand ppm [23]. According to Figure 9 the test room in the $2 \mathrm{X}$ courtyard school is around $20 \%$ less in CO2 concentration than no courtyard school and around $13 \%$ less than $3 \mathrm{X}$ courtyard school. The low concentration of $\mathrm{CO} 2$ levels in the test room in the case of $2 \mathrm{X}$ courtyard school can be explained because of the short local mean age of the air and the high velocity of the air inside it, thus the air inside the test room is renewed faster than the other two cases and that will make the concentration of $\mathrm{CO} 2$ less than the other two cases. As a result the interior spaces (classrooms) in the school with 2 Xcourtyard school have less $\mathrm{CO} 2$ concentration, better ventilation and healthier indoor air quality.

Table 8: CO2 Concentration (ppm) in the test room.

\begin{tabular}{|c|c|}
\hline Simulation cases of the school & CO2 Concentration $(\mathrm{ppm})$ \\
\hline 3X Courtyard & 516 \\
\hline 2X Courtyard & 448 \\
\hline No Courtyard & 567 \\
\hline
\end{tabular}

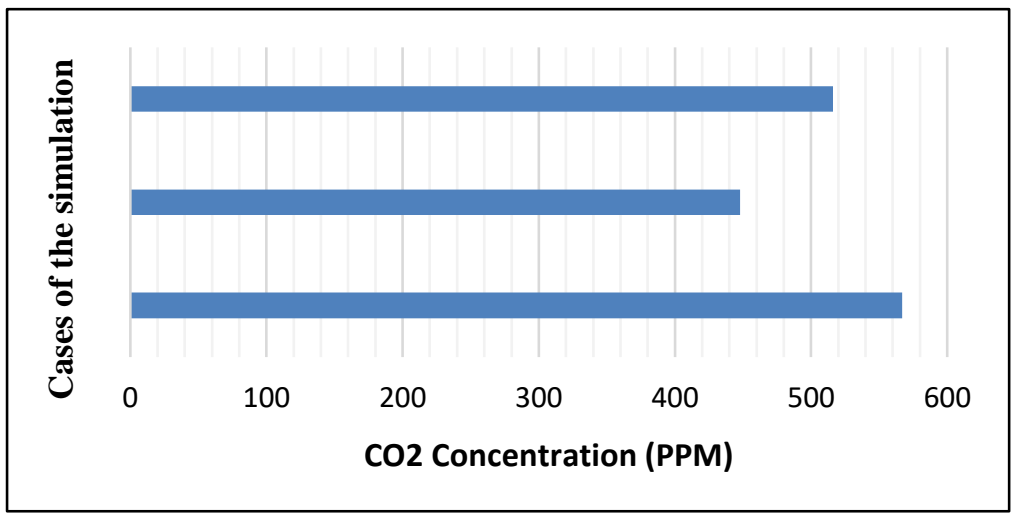

Fig. 9: CO2 Concentration (ppm) in the test room.

\section{Conclusion}

The courtyard was a climate responsive design in the past, that provided people with easy direct solutions for their problems with the climate, and it was able to satisfy their social needs. The courtyard in the present time started to attract the designers as a good passive design solution for the sustainable architecture because of its good thermal performance, but its optimum proportions are still under investigation to reach the desired ratios, which are more suitable for the contemporary architecture. In this study it was clear that the school building with $2 \mathrm{X}$ closed courtyard was better in the thermal performance than the school with no closed courtyard and the one with $3 \mathrm{X}$ closed courtyard as the test room in the $2 \mathrm{X}$ courtyard school had the least air temperature, sun exposure, solar gain consequently the least cooling sensible plant, and that means less energy consumption for cooling. The analysis of CFD showed that the highest air velocity and the least age for local air surface was in interior spaces in the case of $2 \mathrm{X}$ courtyard school, accordingly the air changes faster ( better ventilation) thus reduces $\mathrm{CO} 2$ concentration, and that will create better atmosphere for studying . The final result indicated that the courtyard design strategy have proved its capability in improving the ventilation and the thermal performance of the interior spaces but the courtyard should be in proportions that suits the height and the function of the building. In the case of $\mathrm{Al}$ Murooj English school it is better to have courtyard that has width equal to the double of its height to create sustainable school building which will minimise the energy consumption and satisfy the occupants . 


\section{References}

[1] D. Mumovic, M. Santamouris, A handbook of sustainable building design and engineering. London, Earthscan, 2009.

[2] M. Katanbafnasab, B. Abu Hijleh, "Assessment of the Energy Impact of Using Building Integrated Photovoltaic and Electrochromic Glazing in Office Building in UAE," Engineering, vol. 5, no. 1, pp. 56-61, 2013.

[3] P. Drach, J. Karam-Filho, "Increasing Ventilation by Passive Strategies: Analysis of Indoor Air Circulation Changes through the Utilization of Microclimate Elements," AM, vol. 5, no. 3, pp. 442-452, 2014.

[4] I. Rajapaksha, H. Nagai, M. Okumiya, "A ventilated courtyard as a passive cooling strategy in the warm humid tropics," Renewable Energy, vol. 28, no. 11, pp. 1755-1778, 2003.

[5] H. Abdulkareem, "Thermal Comfort through the Microclimates of the Courtyard. A Critical Review of the Middleeastern Courtyard House as a Climatic Response," Procedia - Social and Behavioral Sciences, vol. 216, pp. 662674, 2016.

[6] J. Reynolds. Courtyards. New York, NY: John Wiley, 2002.

[7] B. Edwards. Courtyard housing. Abingdon, England: Taylor \& Francis, 2006.

[8] R. Hyde. Climate responsive design. London: E \& FN Spon, 2000.

[9] S. Soltanzadeh, "The role of geography on formation courtyards in traditional houses in IRAN," Geographical Research Quarterly, vol. 42, no. 75, pp. 69-86, 2011.

[10] M. Taleghani, M. Tenpierik, A. van den Dobbelsteen, "Energy performance and thermal comfort of courtyard/atrium dwellings in the Netherlands in the light of climate change," Renewable Energy, vol. 63, pp. 486-497, 2014.

[11] H. Koch-Nielsen. Stay cool: a design guide for the built environment in hot climates. London: Earthscan, 2002.

[12] G. Manioğlu, G. Oral, "Effect of Courtyard Shape Factor on Heating and Cooling Energy Loads in Hot-dry Climatic Zone," Energy Procedia, 78, pp. 2100-2105, 2015.

[13] F. Soflaei, M. Shokouhian, S. Mofidi Shemirani, "Investigation of Iranian traditional courtyard as passive cooling strategy (a field study on BS climate)," International Journal of Sustainable Built Environment, vol. 5, no. 1, pp. 99$113,2016$.

[14] A. Almhafdy, N. Ibrahim, S. Ahmad, J. Yahya, "Thermal Performance Analysis of Courtyards in a Hot Humid Climate Using Computational Fluid Dynamics CFD Method," Procedia - Social and Behavioral Sciences, vol. 170, pp. 474-483, 2015.

[15] I. Acosta, M. Campano, J. Molina, "Window design in architecture: Analysis of energy savings for lighting and visual comfort in residential spaces," Applied Energy, vol. 168, pp. 493-506, 2016.

[16] M. Kim, H. Yang, J. Kang, "A case study on controlling sound fields in a courtyard by landscape designs," Landscape and Urban Planning, vol. 123, pp. 10-20, 2014.

[17] A. Jamaludin, H. Hussein, A. Mohd Ariffin, N. Keumala, "A study on different natural ventilation approaches at a residential college building with the internal courtyard arrangement," Energy and Buildings, vol. 72, pp. 340-352, 2014.

[18] N. Zhang, Y. Kang, K. Zhong, J. Liu, "Air Environment and Energy Performance of a Building Courtyard in the Heating Season,” AMM, 501-504, pp. 2231-2239, 2014.

[19] D. Crawle, J. Hand, M. Kummert, B. Griffith, "Contrasting the capabilities of building energy performance simulation programs," Building and environment, vol. 43, no. 4, pp. 661-673, 2008.

[20] G. Hausladen, M. Saldanha, P. Liedl. Building to suit the climate, 2011.

[21] Al Murooj English School map, 2015.2 [Online]. Available: https://www.google.com.sa/maps/place/Al+Murooj+English+Kindergarten+\%26+School+Private/@25.372754,55.4 48392,15z/data $=! 4 \mathrm{~m} 2 ! 3 \mathrm{~m} 1$ !1s0x0:0xf3b9ce11e1c304a3

[22] Anon, 2015. [Online]. Available at: https://www.dewa.gov.ae/images/greenbuilding_eng.pdf

[23] Health.state.mn.us, 2015. Carbon Dioxide (CO2): Environmental Health in Minnesota. [Online]. Available: http://www.health.state.mn.us/divs/eh/indoorair/co2/ 